\title{
Evaluation of Usage and User Satisfaction on Electronic Information Resources and Services: A Study at Postgraduate Institute of Medicine Library, University of Colombo
}

\author{
T. Sritharan ${ }^{1}$
}

\begin{abstract}
This study investigated the level of user satisfaction of electronic information resources and services available at library, Postgraduate Institute of Medicine, University of Colombo. The objective was to determine the level of satisfaction on the use of electronic resources and services by medical postgraduate trainees at Postgraduate Institute of Medicine, University of Colombo. Total number of 427 registered postgraduate medical trainees during the years of 2014 and 2015 was the sample population. Sample size of 100 trainees from 32 medical specialties were selected randomly. Self-administrated questionnaire was used as the data collection instrument. The study revealed that $95.5 \%$ of the respondents have their own computers and Internet connection to access electronic resources. Postgraduate medical trainees use electronic resources for multiple purposes. Among them 98.6 $\%$ of the respondents use the electronic resources for their studies and updating knowledge. Among them $70.5 \%$ of the respondents use electronic resources for gathering general information. Regarding the level of satisfaction on electronic resources and services $60.2 \%$ of the respondents strongly agreed the satisfaction level on provision of Internet access at library, Postgraduate Institute of Medicine. The satisfaction level of subscribed e-journals was agreed by $56.8 \%$ of the respondents. Lack of time to access e-journals at library, lack of training, nonavailability of remote access for subscribed resources were identified as significant issues. Based on the research findings it can be recommended that the library should subscribe more electronic books and journals; more training programs should be arranged; remote access facility should be provided for subscribed electronic sources. Further, mobile alert services should be arranged to make aware about the latest issues and updates.
\end{abstract}

Keywords: Electronic information resources, Electronic information resourcesUsage, Postgraduate Institute of Medicine, Users satisfaction

1 Senior Assistant Librarian, University of Colombo. Email: dayasri92@yahoo.com, https://orcid.org/0000-0001-6282-6172

Received: 16 February 2018, Accepted revised version: 9 May 2018. 


\section{Introduction}

Information is acknowledged as a basic tool for academic and research activities. Thus, information is ranked next to the basic human needs. The major objective of any kind of libraries is to provide right information to the right reader. In order to achieve this objective, library should have quality information resources and services. Due to the rapid development of information and communication technology electronic resources compliment the printed resources in libraries at present. These electronic resources play an integral part of information sources to provide quick and easy services to the readers. Electronic resources are resources in electronic format which can be accessed via Internet in digital library environment and by CDs /DVDs.

Measuring the user satisfaction is one of the vital methods of evaluating the effectiveness of library resources and services. The word satisfaction is defined in Oxford dictionaries as "a fulfilment of one's wishes, expectations or needs". Zeithmal and Bitmar (2003) defined user satisfaction as the means which users determine any products or services meet the required needs and expectations. If the products or services do not meet their needs or expectations, it is therefore assumed that they are dissatisfied with the products or services. Kotler et al. (2009) defined satisfaction as person's feeling of pleasure that result from comparing a product's perceived performance or outcome to their expectation

Health science information services are one of the major concerns in Sri Lanka. The libraries of university medical faculties, libraries attached to Ministry of Health and hospitals, libraries of Postgraduate Institute of Medicine need an improvement to reach a benchmark level in terms of resources and services which are required by health professionals. Though the progress in resource sharing through a health network is available in Sri Lanka, more expansion and developments in providing right information to the right health professional seems to be still far off. The development of health libraries technologies, establishment of health repositories, infrastructure and trained manpower in Sri Lanka is momentum.

Being one and only institute in postgraduate medical education, the Postgraduate Institute of Medicine (PGIM) provides enormous facilities for 
postgraduate medical education with its twenty-two (22) mainboards and thirty four (34) subspecialty boards. The PGIM conducts thirty two (32) MD programs, seven (07) MSc programs and twenty one (21) Diploma programs. The library, PGIM has acquired online journals from the year 2015 (2015 45 e-journals; 2016 - 16 e-journals; 2017-09 e-.journals; 2018 - 45 e.journals and HINARI database). Digital repository is maintained from the year 2010. The catalogue is provided through KOHA library management system and therefore all the resources of the library can be accessed online. E-journals are subscribed based on the recommendation of relevant boards of study. In order to make aware of electronic journals, content page service and article request service were inaugurated in 2015. Content pages of the latest issues are forwarded to all trainees and trainers by e-mail. Full-text articles of those issues can be requested through article request form available at PGIM website. This free service is open to all registered medical professionals in Sri Lanka. The medical professionals who have the SLMC (Sri Lanka Medical Council) registration number are eligible to request articles through this service. Since the library has been mainly moved to electronic environment, it is necessary to evaluate the usage and users' satisfaction with electronic resources by medical postgraduate trainees in Sri Lanka.

\section{Research Objectives}

The general objective of the study was to determine the users' satisfaction with electronic information resources and services provided to medical postgraduate trainees by the postgraduate Institute of Medicine, University of Colombo. Specific objectives were to:

i. Identify the usage pattern of electronic information resources by postgraduate medical trainees

ii. Identify the purposes of using electronic resources available in the Library, PGIM.

iii. Determine the level of satisfaction with the use of electronic resources and services by medical postgraduate trainees.

iv. Identify the major issues and concerns in using electronic resources

v. Provide suitable recommendations to improve the usage of electronic resources by medical postgraduate trainees. 


\section{Literature Review}

User studies are one of the most important areas of research in library and information science. All these studies were carried out to assess the users' expectations, users' needs and wants. These studies were pointing out the particular sources used by readers and different obstacles or barriers which were influencing the usage pattern. According to Daisy (2006), every information service exists for the sole aim of satisfying the users.

Eager and Oppenheim (1996) ascertains that "assessment of library users satisfaction can provide invaluable information to libraries to re-orient their library collection, services and library activities for effectively meeting their information needs". In the same way the importance of user satisfaction survey is impressed by Vijeyaluxmy (2015) in her study that "in depth user satisfaction surveys should be conducted by the libraries regularly to find out the changing environment requirement of users". Andaleep and Simmonds (1998) says that "the effectiveness of library services can be evaluated by user satisfaction". Hiller, (2001) views that "library user satisfaction surveys have become widespread during the last two decades". User satisfaction is based on the degree of perceived quality that meet users expectations, therefore library management must regularly evaluate the services they provide to the users. It is an evident from the above statements that user assessment is considered most suitable for measuring effectiveness of libraries.

Due to the rapid development of information technology all kind of libraries have challenges in having resources in electronic and traditional format. Rani and Chinnasamy (2014) say that "E-resources are those resources which include documents in electronic or e-format that can be accessed via Internet in digital library environment; E-resources are that electronic product that delivers a collection of data, text messages, image collection, other multimedia products like numerical, graphical mode for commercially available for library and information centres. These may be delivered on CDROM / DVD, over the Internet and so on".

Interaction with electronic devices has increased in all aspects of knowledge work including information seeking behaviour (Marchionini, 1995). The academic libraries are spending an amount of allocation for subscription to 
online resources. The noticeable shift from print to electronic information sources and services intends to do the assessment of satisfaction level at present libraries. Also the impact of online resources and amount of allocation for subscription to electronic resources has heightened the interest among librarians to evaluate the electronic usage pattern and the level of satisfaction of users on electronic information services. According to the study by Ibrahim, (2004) most of the respondents were somewhat satisfied (23\%) with the electronic resources and services the deanship provided. In the same way study by Patrick, Aghojare and Ferdinand (2015) indicated that $62 \%$ of the respondents were highly satisfied with provided longer hours for Internet access and $85 \%$ of the respondents highly satisfied with giving access to e-books and e-journals.

Most of the libraries are embracing to subscribe electronic journals and planning to reduce the subscription of print journals to meet the assumption of users as well as it helps to reduce the overload of reprographic service and document (Mishra, Ramesh, Nanda, \& Khuntia, 2015).

In Sri Lankan context handful of studies analysed the usage of electronic resources at libraries. Very few studies discuss about the user satisfaction level of electronic resources and services. The study conducted by Hindagolla (2017) reveals that "majority of the $(86 \%)$ arts undergraduates in Peradeniya University were satisfied with the information sources and services provided by digital library. The research findings of Pieris and Peiris (2012) and Karunarathna (2014) confirmed that users prefer to use electronic resources than printed resources. Wijetunge (2017) revealed from the study of use of electronic resources by librarian in Sri Lanka that $65 \%$ of the librarians frequently use open access resources for their research work. Also this study attempted to identify the factors which affect the usage of electronic resources. Inability to access the subscribed sources from home was the most often given reason for not using electronic resources.

The access of electronic resources is influenced by several factors. The access of electronic information resources can be influenced by information literacy and skill in accessing information of the users. Millawithanachchi (2012) identified nine variable factors which influence the electronic access. 
Among them the technology was the most critical factor of postgraduate students at university of Colombo.

\section{Methodology}

The survey method by using questionnaire was used to collect data from medical postgraduate trainees. This paper is a part of a large study on critical evaluation of information seeking behavior of medical postgraduate trainees with the use of electronic resources. The general population of this study was 427 medical postgraduate trainees registered for the MD courses from 32 medical specialties in 2014 and 2015. Sample size of 100 trainees from 32 medical specialties were selected randomly. The self-administrated questionnaire was used to collect data. Questionnaire consisted of twentyfour main questions regarding general information, usage of electronic resources, level of satisfaction on electronic resources and services, preferred method of information resources and major issues and concerns on accessing electronic resources. Majority of the questions were structured and very few questions were opened. Questionnaires were issued by hand at library, PGIM in order to get the maximum response. Data was directly entered to SPSS for data analysis.

\section{Ethical Review}

Ethical approval was taken from the ethical committee of faculty of Graduate studies, University of Colombo. (Application number: FGS/ERC/2017/004). After the ethical approval participants were informed that the information obtained would be confidential and would use only for this research study. Information sheet was provided in advance along with the consent form which was read and signed by the participants. In the information sheet participants were made aware that they are free to withdraw from the study at any time

\section{Results and Discussion}

A total number of eighty-eight completed questionnaires were received out of one hundred giving an overall response rate of $88 \%$. In this survey results showed that $71.6 \%$ (63) of the respondents are female and $28.4 \%$ (25) of the respondents are male. All the respondents are under the age group of 29-49. Among them, 59 respondents were in the age group of 29-39 years and 29 were in the age group of 40-49 years. 


\section{Usage of Electronic Resources}

Electronic information environment is very important for the improvement of electronic information services. To use the electronic resources, the minimum requirements are computers and Internet connection. Printing facility is the additional requirement for the electronic resources. In order to improve the electronic resources usage there was a separate section organised at the PGIM library. To know the electronic information environment users were asked to mention the availability of computer, Internet and printing facilities at home and institutions. The results are displayed in Figure 1 . The results revealed that $95.5 \%$ (84) of the respondents have computers at home with internet connection.

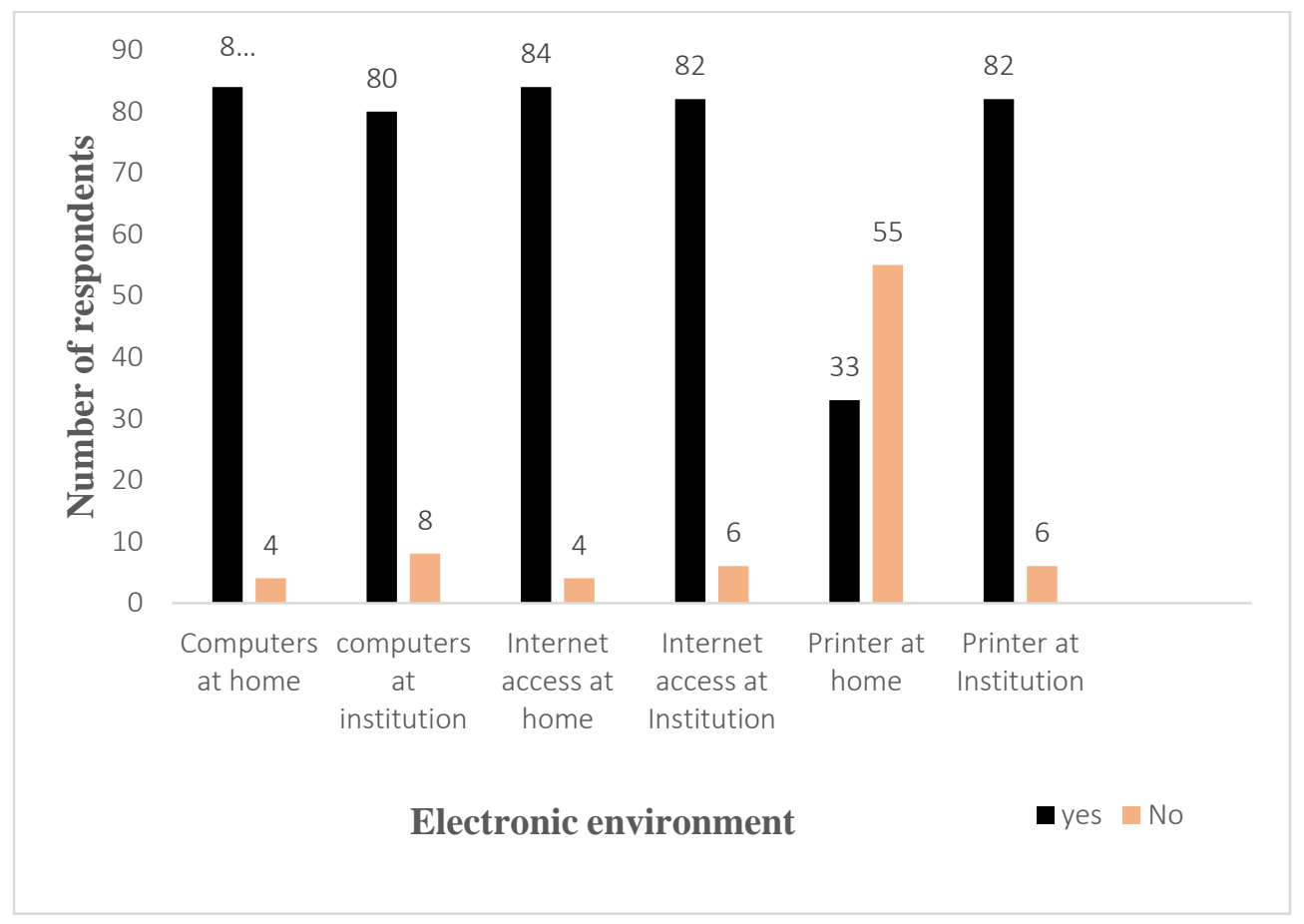

Figure 1. Electronic environment for accessing resources

\section{Place of Accessing Electronic Resources}

After registration of medical postgraduate trainees, they are appointed island wide hospitals for their clinical practice and experience. While they are doing their clinical practises they have to do references for their final examination and research submission. So during their clinical practises they 
use different libraries such as hospital libraries, medical faculty libraries, Ministry of health library and Postgraduate Institute of medicine branch library in Kandy. In order to know the place of accessing electronic resources they were asked to mention the place of accessing electronic resources. They were allowed to answer as many as that applies to them. The Table 1 highlights places of access of electronic resources.

Table 1. Place of access

\begin{tabular}{llc}
\hline Place of access & Frequency & Percentage \% \\
\hline PGIM main library and branch library & 50 & 56.7 \\
Ministry of health library and hospital libraries & 20 & 22.8 \\
Faculty libraries & 18 & 20.5 \\
Total & 88 & 100.0 \\
\hline
\end{tabular}

From the above Table, it is seen that Postgraduate Institute of Medicine library and branch library are highly used by postgraduate medical trainees (56.7\%). It is followed by Ministry of health library and hospital libraries $(22.8 \%)$.

\section{Sources of Getting Information}

As shown in the Table 2, respondents indicated their main source of information which they use to seek information. Hence it is observed that textbooks are highly used by the respondents $(71.4 \%)$ followed by general internet sources 60 (68.1\%) and electronic journals 40 (45.4\%).

Table 2. Sources of getting information

\begin{tabular}{lll}
\hline Sources & Frequency & Percentage \% \\
\hline Textbooks & 63 & 71.4 \\
Print journals & 12 & 12.4 \\
Colleagues & 11 & 12.4 \\
Collages & 07 & 7.9 \\
Electronic journals & 40 & 45.4 \\
General Internet resources & 60 & 68.1 \\
\hline
\end{tabular}

Note: Respondents could choose multiple options

Respondents were asked to indicate the time duration spent for reading print resources and electronic resources daily. The study revealed that most of the 
respondents spent 1-2 hours per day for gathering information from print as well as electronic resources (Figure 2).

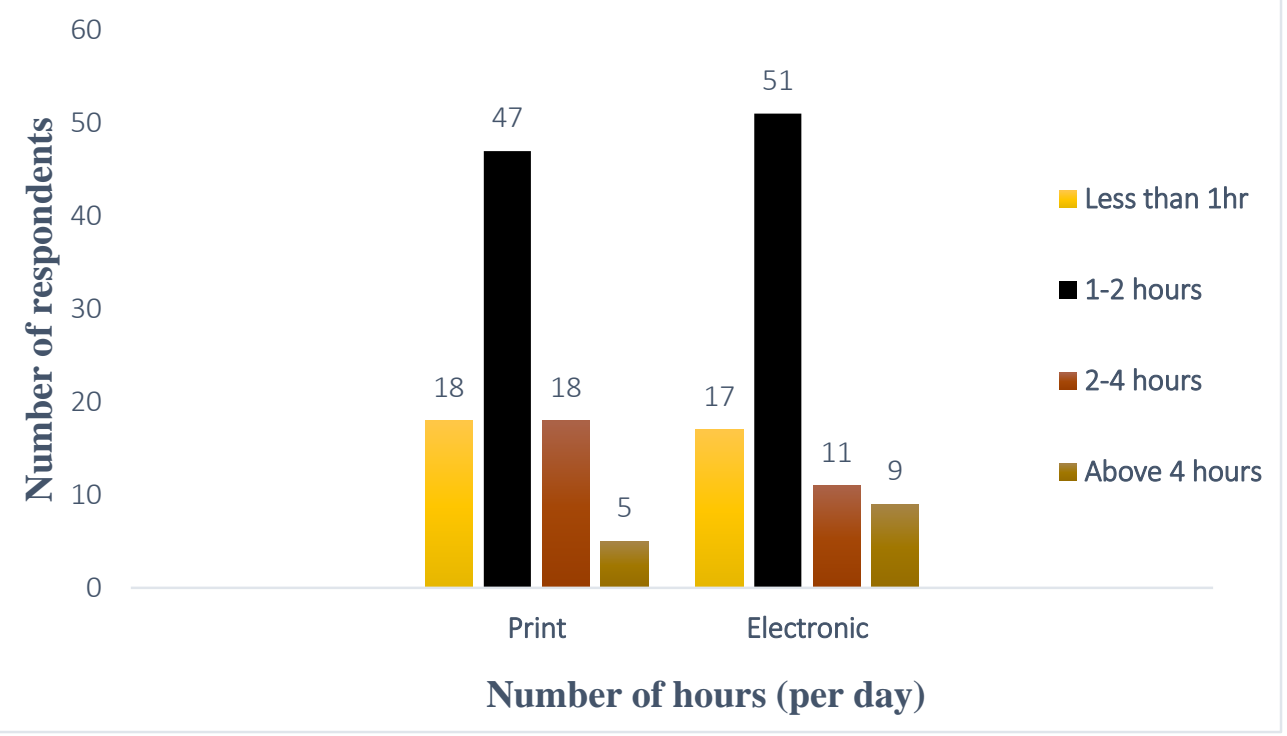

Figure 2. Time duration spent for gathering information from print and electronic resources

Purpose and Frequency of Using Electronic Resources

Electronic resources are used for various purposes in higher education institutes. Rehman and Ramzy (2004) analysed the awareness and use of electronic resources among health libraries and the study revealed that the electronic resources are extensively used for research and preparation of lectures. According to the Table 3, it is observed that most of the respondents (98.6\%) use electronic resources for learning and updating knowledge; 71.6 $\%$ of the respondents use electronic resources for their research work; 70.5\% of the respondents use for to gather general information.

It is referred from the Table 4 that $70.5 \%$ (62) of the respondents use electronic resources daily. This is a good sign for library and $21.6 \%$ (19) of the respondents use electronic resources once a week. Among them $4.5 \%$ (04) of the respondents use twice a week and 3.4\% (03) of the respondents use once in a month. 
Table 3. Purpose of using electronic resources

\begin{tabular}{llllll}
\hline \multirow{2}{*}{ Response } & \multicolumn{5}{c}{ Purpose of using electronic resources } \\
\cline { 2 - 6 } & Research & $\begin{array}{l}\text { Learning and } \\
\text { knowledge } \\
\text { update }\end{array}$ & $\begin{array}{l}\text { To } \\
\text { complete } \\
\text { course work }\end{array}$ & $\begin{array}{l}\text { Clinical } \\
\text { practice }\end{array}$ & $\begin{array}{l}\text { General } \\
\text { information }\end{array}$ \\
\hline Yes & $63(71.6 \%)$ & $85(98.6 \%)$ & $57(64.8 \%)$ & $52(59.1 \%)$ & $62(70.5 \%)$ \\
No & $25(28.4 \%)$ & $03(3.4 \%)$ & $31(35.2 \%)$ & $36(40.9 \%)$ & $26(29.5 \%)$ \\
Total & $88(100 \%)$ & $88(100 \%)$ & $88(100 \%)$ & $88(100 \%)$ & $100(100 \%)$ \\
\hline
\end{tabular}

Table 4. Frequency of using electronic resources

\begin{tabular}{llr}
\hline & Frequency & Percent \\
\hline Daily & 62 & 70.5 \\
Once a week & 19 & 21.6 \\
Twice in a week & 04 & 4.5 \\
Once in a month & 03 & 3.4 \\
Total & 88 & 100.0 \\
\hline
\end{tabular}

Level of Satisfaction on Electronic Resources and Services

As shown in the Table 5, satisfaction level with the provision of free access to internet provided by library was are strongly agreed by 53 (60.2\%) respondents. The satisfaction level of subscription of electronic resources was also strongly agreed by 50 (56.8\%) respondents. The satisfaction level of awareness on availability of electronic resources, user education programs and the current awareness services was agreed by less than $50 \%$ of the respondents. Regular maintenance of ICT infrastructure at library (S6) was strongly agreed by only $22.7 \%$. Satisfaction level of support of the library staff (S7) was agreed by $25 \%$ of the respondents.

According to Table 5, it is evident that majority of respondents were strongly agreed with the provision of free access to Internet by library and subscription of electronic resources. It is noted that less than $30 \%$ of the respondents were strongly agreed on ICT infrastructure of library and library staff support to access electronic resources and services. Though $6.8 \%$ of the respondents did not have any idea about the support of library staff $93.2 \%$ of them recognize the same. None of them do have a disagreement about the support of the library staff. Respondents feedback on level of satisfaction on 
the awareness on availability of electronic resources is somewhat high and $80.6 \%$ respondents strongly agree or agree on this statement.

User education programs and current awareness services carried out by the library has been recognized and more than $60 \%$ of the respondents by strongly agreeing or agreeing on these statements. It is also evident from the Table 5, considerable percentage of respondents not in a position to decide on library user education programs and current awareness services carried out by the library (19.3\% and 31.8\% respectively).

\section{Table 5. Level of satisfaction on electronic resources and services}

\begin{tabular}{|c|c|c|c|c|c|c|c|}
\hline & $\begin{array}{l}\text { Provision } \\
\text { of free } \\
\text { access to } \\
\text { Internet }\end{array}$ & $\begin{array}{l}\text { subscription } \\
\text { of electronic } \\
\text { resources }\end{array}$ & $\begin{array}{l}\text { awareness } \\
\text { on } \\
\text { availability } \\
\text { of } \\
\text { electronic } \\
\text { resources }\end{array}$ & $\begin{array}{l}\text { user } \\
\text { education } \\
\text { programs }\end{array}$ & $\begin{array}{l}\text { current } \\
\text { awareness } \\
\text { services }\end{array}$ & $\begin{array}{l}\text { Regular } \\
\text { maintenance } \\
\text { of ICT } \\
\text { infrastructure }\end{array}$ & $\begin{array}{l}\text { support } \\
\text { of the } \\
\text { library } \\
\text { staff }\end{array}$ \\
\hline $\begin{array}{l}\text { Strongly } \\
\text { agree }\end{array}$ & 60.2 & 56.8 & 38.6 & 31.8 & 26.1 & 22.7 & 25.0 \\
\hline Agree & 28.4 & 25.0 & 42.0 & 39.8 & 36.4 & 43.2 & 68.2 \\
\hline Undecided & 3.4 & 14.8 & 15.9 & 19.3 & 31.8 & 28.4 & 6.8 \\
\hline Disagree & 8.0 & 3.4 & 3.4 & 9.1 & 5.7 & 5.7 & 0.0 \\
\hline $\begin{array}{l}\text { Strongly } \\
\text { disagree }\end{array}$ & 0.0 & 0.0 & 0.0 & 0.0 & 0.0 & 0.0 & 0.0 \\
\hline Total & 100.0 & 100.0 & 100.0 & 100.0 & 100.0 & 100.0 & 100.0 \\
\hline
\end{tabular}

\section{Major Issues and concerns}

The Table 6 shows the major issues and concerns mentioned by respondents regarding the electronic resources and services at the library.

Overall results indicate that lack of computers at the PGIM library (73\%), lack of training (62.5\%), lack of time (65.9\%), slow access and downloading (83.0\%) and no remote access to subscribed sources were perceived to be major issues. 
Table 6. Major issues and concerns

\begin{tabular}{lrl}
\hline \multicolumn{1}{c}{ Issues } & \multicolumn{1}{l}{ Yes } & No \\
\hline Lack of computers at the PGIM library & $73(83.0 \%)$ & $15(17.0 \%)$ \\
Lack of searching skills & $39(44.3 \%)$ & $49(55.7 \%)$ \\
Lack of training & $55(62.5 \%)$ & $33(37.5 \%)$ \\
Lack of guidance & $43(48.9 \%)$ & $45(51.1 \%)$ \\
Difficult in finding relevant information & $37(42.0 \%)$ & $51(58.0 \%)$ \\
Lack of resources in my subject & $33(37.5 \%)$ & $55(62.5 \%)$ \\
Lack of time & $58(65.9 \%)$ & $30(34.1 \%)$ \\
Lack of library staff support & $15(17.0 \%)$ & $73(83.0 \%)$ \\
Slow access and downloading & $73(83.0 \%)$ & $15(17.0 \%)$ \\
No remote access to subscribed resources & $62(70.5 \%)$ & $26(29.5 \%)$ \\
Too much of information & $9(10.2 \%)$ & $79(89.8 \%)$ \\
Required information not available & $31(35.2 \%)$ & $57(64.8 \%)$ \\
Unable to access full text articles & $22(25.0 \%)$ & $66(75.0 \%)$ \\
Lack of access to previous resources & $37(58.0 \%)$ & $51(42.0 \%)$ \\
\hline
\end{tabular}

Hence, several suggestions are made to uplift the usage of electronic resources and services of PGIM Library:

- Add more computers to the PGIM Library and Peradeniya Branch Library; Arrange workshops on electronic resources access;

- Providing tabs and laptops for trainees; Practical lessons on computer skills for PG trainees;

- Introduce an IT literacy module with the postgraduate medical education curriculum;

- Introduce remote access for subscribed sources; Awareness programs for available resources;

- Subscribe more e-resources especially e-books;

- Provide proper lighting and air conditioning to the library in order to stay for a long time. 


\section{Conclusion}

Out of 88 respondents, 25 were males and 63 were females participated in this study. All respondents are in the age group of 29-49. Among them 95.5\% of the respondents have their own computers with Internet connection at their homes. More than half of the respondents (56.7\%) use the Postgraduate Institute of Medicine main library and branch library for their electronic resources access.

Half of the respondents spend 1-2 hours daily to gather information from print and electronic resources at library. Electronic resources are used for different purposes; $98.6 \%$ of the respondents use electronic resources for the purpose of studying and updating knowledge; $71.6 \%$ of the respondents use electronic resources for their research purposes. $70.5 \%$ of the respondents use electronic resources daily. Regarding the satisfaction level of provision of free access to the Internet, it was strongly agreed by $60.2 \%$ (53) of the respondents; satisfaction level of subscription of electronic resources by Postgraduate Institute of Medicine was agreed by $56.8 \%$ (50) of the respondents; satisfaction level of awareness services of electronic resources was agreed by less than $50 \%$ of the respondents. Lack of computers at the library, lack of training, slow access and downloading and no remote access for subscribed electronic resources were identified as major issues by the respondents.

\section{Recommendations}

Since more than half of the trainees (56.7\%) use the PGIM library and branch library, these libraries should be expanded with space, computers and internet connection. Facilities such as computers with speed internet connection at PGIM library and branch library, proper lighting and airconditioning should be arranged to increase the reading hours by 3-4 hours or more than 4 hours. Electronic resources should be subscribed based on the prospectus of each courses in order to utilize the resources for research purpose. Citation analysis study should be conducted to identify the relevant electronic resources related to the research work. Mobile article alert service or other social media programs can be started to make aware about the recent updates or latest issues of electronic resources. The remote access facility should be provided for subscribed resources with the support of IT experts. 
Orientation programs, practical training sessions, seminars should be conducted to train them in order to access most relevant e-resources.

\section{References}

Andaleep, S. S. \& Simmonds, P. L. (1998). Exploring user satisfaction with academic libraries: Strategic implications. College and Research Libraries. 156-167. Retrieved from http://crl.acrl.org/index.php/crl/article/view/15193/16639

Eager, C \& Oppenheim, C. (1996). An observational method for undertaking user needs studies. Journal of Librarianship and Information Science 28(1), 15-23. http//:doi.org/10.1177/096100069602800103

Hiller, S. (2001). Assessing user needs, satisfaction and library performance at the university of Washinton libraries. Library Trends, 49(1). 605-625. Retrieved from https://www.libqual.org/documents/admin/Hiller.pdf

Hindagolla, B. M. M. C. B. (2017). The use of digital library by art undergraduates in Sri Lanka: a case study at University of Peradeniya. International Journal of Social sciences. 3(2), 2260-2278. Retrieved from https://www.grdspublishing.org/index.php/people/article/viewFile/764/672

Ibrahim, A. E., (2004). Use and user perception of electronic resources in the United Arab Emirates University (UAEU). Libri, 18-29. http//:doi.org/ $=10.1 .1 .508 .8115 \&$ rep=rep1\&type=pdf

Karunarathna, H. M. P. P. (2014). Use of electronic resources by law degree students at Anuradhapura Regional Centre of the Open University of Sri Lanka. Journal of the University Librarians Association of Sri Lanka, 18(2), 41-61.

Kotler, P., Lane, K. K., Koshy, A \& Jha, M. (2009). Marketing management: A South Asian perspective. New Delhi: Prentice Hall.

Marchionini, G. (1995). Information seeking in electronic environments. New York: Cambridge University Press.

Millawithanachchi, U. S. (2012). Electronic resources usage by Postgraduates at the University of Colombo: Identifying the critical success factors, Annals of Library and Information Studies, 59, 53-63. 
Mishra, M., Ramesh, D. B., Nanda, J. S. \& Khuntia, S. K. (2015). Study on Information need and Seeking Behavior of the Health Science Students of an Indian Deemed University. Library Philosophy and Practise Retrieved from file://F:/PhD/New\%20folder\%20All\%20articles\%20PhD/MIShra\%20ISB.pdf.

Patrick, I. O., Aghojare \& Ferdinand (2015). Assess users' satisfaction on academic library performance: a case study. International Journal of Academic Research and Reflection, 3(5). 67-77.

Peiris, N. D. \& Peiris, B. L . (2012). An assessment of undergraduate students' usage of e-resources to fulfil their information needs: a case study at university of Peradeniya. Sri Lanka Library Review, 26, 30-43.

Rani, S. \& Chinnasamy, K. (2014). A study on users' satisfaction of electronic resources and services in the self-financing colleges affiliated to Madurai Kamaraj University. International Journal of Interdisciplinary and Multidisciplinary Studies (IJIMS), 1(6), 223-230. Retrieved from http://www.ijims.com/uploads/e6cacf26962b77ebd2a1z29.pdf

Rehman, S. \& Ramzy, V., (2004) Awareness and use of electronic information resources at the Health Sciences Center of Kuwait University. Library Review, 53(3). 150-156. http://doi.org/ 10.1108/00242530410526556.

Seneviratne, D. (2006). Measuring user satisfaction: A case study at the PGIM branch library at Peradeniya. Journal of the University Librarians Association of Sri Lanka, 18(2). 10, 40-53.

Vijeyaluxmy, S. (2015). Students' satisfaction with library services in an academic library: special reference to Trincomalee campus. Paper presented at $5^{\text {th }}$ International symposium, SEUSL. Oluvil. Retrieved from http://www.seu.ac.lk/researchandpublications/symposium/5th/libraryandi nformationscience/13.pdf

Wijetunge. P. (2017). Usage of electronic resources by librarians of Sri Lankan Universities. Annals of Library and information studies. 64(1), 21-27. Retrieved from http://op.niscair.res.in/index.php/ALIS/article/view/14125/0. 
Journal of the University Librarians Association of Sri Lanka, Vol.21, Issue 2, July 2018, 73-88 DOI: https://doi.org/10.4038/jula.v21i2.7918

Zeithaml, V. \& Bitmar, M. J. (2003). Service marketing: Integrating customer focus across the firm. Boston: McGraw-Hill. 